\title{
CORRECTIONS
}

\section{NHS is urged to buy ethically}

In the pdf of the In Brief column published in the print issue of 26 March (BMJ 2011;342:d1867, doi:10.1136/bmj.d1867), we said that the BMA and the Department of Health had produced a report on ethical procurement in the NHS. That was incorrect. What we should have said is that an online workbook, which will support ethical procurement in NHS organisations, will be published by the BMA and the Ethical Trading Initiative on 16 May.

Cite this as: $B M J$ 2011;342:d2014 